\title{
СЛАВНИЙ ЮВІЛЕЙ ПРОФЕСОРА ВАЛЕНТИНИ ІВАНІВНИ ЗАДОРОЖНОЇ
}

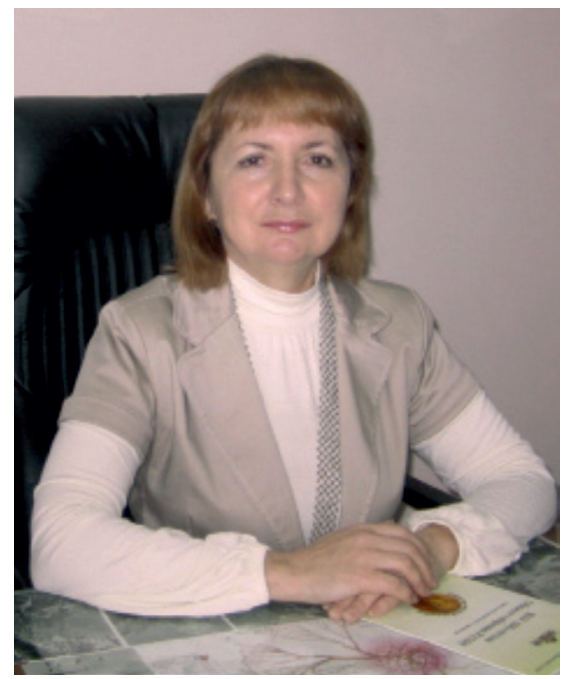

Доктор медичних наук, професор В.І. Задорожна $€$ провідним українським вченим у галузі епідеміології інсрекційних хвороб, вакцинології та вірусології. Фундаментальні та прикладні дослідження ювілярки спрямовані на розвиток молекулярної епідеміології вірусних інфекцій, розкриття механізмів взаємовідносин вірусу та хазяїна в паразитарній системі, оптимізацію схем імунізації, що загалом сприяє підвищенню ефективності профрілактики інфрекційних хвороб та контролю інтенсивності епідемічного процесу.

Трудову діяльність В.І. Задорожна розпочала в Київському науково-дослідному інституті інсрекційних хвороб МОЗ України на посаді лікаря-вірусолога (1980-1982рр.). Наукова діяльність пов'язана з Інститутом епідеміології та інфрекційних хвороб ім. Л.В. Громашевського НАМН України, де працювала послідовно на посадах молодшого, старшого, провідного наукового співробітника (1980-1996 рр.), згодом - завідувача лабораторії екології мікроорганізмів, завідувача лабораторії поліомієліту та інших ентеровірусних інфекцій. 31999 по 2005 р. поєднувала наукову роботу з викладацькою, працюючи на кафредрі мікробіології, вірусології та імунології Національного медичного університету імені О.О. Богомольця на посаді доцента. 32006 р. по 2011 р. була заступником директора з наукової роботи ДП «Центр імунобіологічних препаратів» МОЗ України, з листопада 2011 по липень 2013 р. - заступником директора Департаменту медичних імунобіологічних препаратів та імунопрофрілактики ДП «Державний експертний центр МО3
України». Із липня по грудень 2013 р. виконувала обов'язки директора ДУ «Інститут епідеміології та інсрекційних хвороб ім. Л.В. Громашевського НАМН України», починаючи 3 грудня 2013 р. - директор цього інституту, а також очолює відділ епідеміологічного аналізу та вакцинопрофрілактики.

У 1988 р. захистила кандидатську дисертацію «Циркуляція поліовірусів серед різних контингентів населення та в об'єктах навколишнього середовища», у 1996 р. - докторську дисертацію „Епідеміологія ентеровірусних інсрекцій в Україні», у 2002 р. їй присвоєно вчене звання профресора.

Наукове обґрунтування В.І. Задорожною стратегії та тактики ерадикації поліомієліту з подальшою участю в їх реалізації дозволило припинити циркуляцію „дикого» поліовірусу в Україні завдяки досягненню достатнього рівня несприйнятливості населення, а її територію у складі Європейського регіону ВООЗ у 2002 р. сертифрікувати як вільну від цієї хвороби. Велику і незаперечну участь у цьому профресора В.І. Задорожної офріційно визнано керівництвом Європейським бюро ВООЗ і відзначено іменним сертифрікатом-подякою та почесним знаком.

На підставі вивчення кореляційної залежності між рівнями післявакцинального імунітету проти поліомієліту та кількістю щеплень було принципово змінено підходи до ревакцинації проти цієї інфекції та зменшено загальну кількість щеплень 39 до 6. У подальшому було проведено глибокі клініко-епідеміологічні дослідження з метою визначення оптимальних, в умовах нашої країни, схем імунізації проти поліомієліту та впроваджено інактивовану поліомієлітну вакцину. Це дозволило на тлі належного рівня охоплення імунопрофілактикою населення України припинити захворюваність на вакциноасоційований поліомієліт серед реципієнтів вакцини, знизити інтенсивність циркуляції вакцинних поліовірусів та ризик фрормування серед них варіантів зі зміненими генетичними властивостями, здатних викликати ураження нервової системи.

Під керівництвом В.І. Задорожної вперше в Україні було виділено та ідентифріковано штами ентеровірусу типу 71 (1998 р.), що є збудником «хвороби рота, рук та ніг» та викликає широкомасштабні епідемії в Азійському регіоні; було ідентифріковано перший в Україні штам вірусу пандемічного грипу (2009р.) A(H1N1)pdm09.

При її безпосередній участі створено Лабораторію 3 контролю медичних імунобіологічних препаратів ДП «Державний експертний центр» (2009-2013 рр.), Науковий центр 
грипу та гострих респіраторних інсекцій та Медичний центр інсрекційних уражень нервової системи на базі ДУ «Інститут епідеміології та інфекційних хвороб ім. Л.В. Громашевського НАМН України" (2014р.).

2014 р. у зв'язку із початком епідемії хвороби Ебола в Західній Африці В.І. Задорожна брала безпосередню участь в оцінці епідемічних ризиків для України цієї інфрекції, розробці нормативної документації щодо запобігання завозу вірусу в Україну та його поширенню, в організації міжвідомчих тренувальних навчань із відпрацювання алгоритму протидії епідемічним ризикам.

Під керівництвом професора В.І. Задорожної захищено 7 кандидатських та 3 докторські дисертації (науковий консультант). Вона $€$ автором 466 наукових праць, зокрема 5 монографрій та навчальних посібників, має 4 патенти. Результати її наукової діяльності ввійшли до значної кількості нормативних документів Кабінету Міністрів та МОЗ України.

За активну участь у розвитку вітчизняної науки, зміцненні науково-технічного потенціалу України В.І. Задорожна відзначалася грамотами НАМН, МОЗ України, Київської міської ради.

В.І. Задорожна була головою спеціалізованої Вченої ради зі спеціальності «епідеміологія» (2002-2008 рр.), заступником голови Українського наукового медичного товариства мікробіологів, епідеміологів і паразитологів ім. Д.К. Заболотного (2005-2014рр.), членом спеціалізованої Вченої ради Д 26.003.01 зі спеціальності «вірусологія» Національного медичного університету імені О.О. Богомольця (2004-2013 рр.), головою Сертифрікаційного комітету з ерадикації поліомієліту МОЗ України (2012-2015рр.),
Львівського відокремленого осередку громадської організації «Українська асоціація біобезпеки» (УАБ).

Задорожна В.І. є головою Вченої ради Д 26.614.01 зі спеціальностей «вірусологія», «епідеміологія», «інфрекційні хвороби», головним редактором журналу «Профрілактична медицина», членом редакційної колегії науково-практичного медичного журналу „Інфекційні хвороби”, головою проблемної комісії МОЗ та. НАМН України «Епідеміологія та специфічна профрілактика інфекційних захворювань», науковим консультантом щотижневого Інсрормаційного» бюлетеню «Грип та ГРВІ в Україні» ДЗ «Український центр 3 контролю та моніторингу захворювань МОЗ України», головою консультативно-експертної групи з розробки розділу «Вакцини та анатоксини» Державного формуляра, головою консультативної експертної групи «Вакцини та імунологічні препарати» ДП «Державний експертний центр МОЗ України».

Прекрасні людські якості, високий професіоналізм і досвід, великі наукові здобутки, сумлінна самовіддана праця профресора В.І. Задорожної є взірцем для молодого покоління вчених і лікарів.

Щиро вітаємо вельмишановну Валентину Іванівну Задорожну з ювілеєм та бажаємо їй безмежного щастя, міцного здоров'я, життєвої енергії, родинного благополуччя, втілення творчих планів і натхнення в роботі на довгі роки!

Колектив Інституту епідеміології та інфрекційних хвороб ім. Л.В. Громашевського НАМН України, редакція журналу «Інсрекційні хвороби», президія Всеукраїнської асоціації інфрекціоністів. 